\title{
HUBUNGAN PENGETAHUAN DENGAN SIKAP REMAJA PUTRI TENTANG REBUSAN DAUN SIRIH DALAM MENGATASI KEPUTIHAN DI SMAN 11 PEKANBARU
}

\author{
Rafika Oktova \\ Program Studi D-III Kebidanan, STIKes Payung Negeri Pekanbaru \\ Email: rafikamkeb@gmail.com
}

\begin{abstract}
Correlation the Knowledge with Attitude of Adolescent Girls about Betel Leaf Decocta to Treat Fluor Albus in SMAN 11 Pekanbaru 2016. Leucorrhea known as whitish or "fluor albus" can caused by infection, reproductive organs of abnormality or cervical cancer. In 2003 , about $60 \%$ Indonesian women had whitish and about $70 \%$ women had whitish at least once in a lifetime, in 2004. At the moment, therapy herbs have been started to develop, one herbs is betel leaf which efficacious to treat whitish. This study was to know the correlation between knowledge with attitude of adolescent girl about betel leaf decocta to treat whitish in SMAN 11 Pekanbaru 2016. This study was cross sectional design. Population was all the students of SMAN 11 Pekanbaru, total population were 432 people, and total samples were 82 respondent. Data analyzed by chi-square $(\alpha<0,05)$. The result showed that most of respondent had a knowledge about betel leaf decocta as herbs to treat whitish, as much as 51 people $(62,20 \%)$ and a small number did not know, as much as 31 people $(37,80 \%)$. Based on attitude, most respondents be positive about betel leaf decocta to treat whitish, were about 62 people $(75,60 \%)$ and a small number who have negative attitude were about 20 people $(24,40 \%)$. The result statistical test chisquare showed that there was correlation the knowledge with attitude of adolescent girl about betel leaf decocta to treat whitish ( $p$-value $=0,002$ dan $\mathrm{OR}=6,176$ ).
\end{abstract}

Keywords: Knowledge, Attitude, Betel leaf decocta, Fluor albus

\begin{abstract}
Abstrak: Hubungan Pengetahuan dengan Sikap Remaja Putri Tentang Rebusan Daun Sirih Dalam Mengatasi Keputihan Di SMAN 11 Pekanbaru Tahun 2016. Keputihan dikenal sebagai leucorrhea atau flour albus yang disebabkan oleh infeksi kelainan organ reproduksi atau kanker leher rahim. Di Indonesia, tahun 2003 sebanyak 60\% wanita mengalami keputihan dan 70\% pada tahun 2004 wanita mengalami keputihan setidaknya sekali dalam seumur hidup. Pada saat sekarang ini, terapi herbal mulai berkembang salah satunya adalah tanaman daun sirih yang berkhasiat untuk pengobatan keputihan. Tujuan penelitian mengetahui hubungan antara pengetahuan dengan sikap remaja putri tentang rebusan daun sirih dalam mengatasi keputihan di SMAN 11 Pekanbaru. Penelitian ini adalah analitik desain cross sectional. Populasi penelitian adalah seluruh siswi SMAN 11 Pekanbaru berjumlah 432 orang. Sampel berjumlah 82 orang. Analisa data dengan uji chi-square $(\alpha<0,05)$. Hasil penelitian menunjukkan bahwa sebagian besar responden pengetahuan kategori tahu berjumlah 51 orang $(62,20 \%)$ dan sebagian kecil responden tidak tahu sebanyak 31 orang $(37,80 \%)$. Berdasarkan sikap responden sebagian besar responden bersikap positif tentang rebusan daun sirih dalam mengatasi keputihan yaitu sebanyak 62 orang $(75,60 \%)$ dan sebagian kecil mempunyai sikap negatif yaitu sebanyak 20 orang $(24,40 \%)$. Hasil uji statistik chi-square menunjukkan bahwa terdapat hubungan antara pengetahuan dengan sikap remaja putri tentang rebusan daun sirih dalam mengatasi keputihan dengan nilai $p$-value $=0,002$ dan $\mathrm{OR}=6,176$.
\end{abstract}

Kata kunci: Pengetahuan, Sikap, Rebusan daun sirih, Keputihan

Keputihan karena faktor fisiologis biasanya berbentuk lendir encer, bening, dan tidak busuk.Hal ini sangat berbeda dengan keputihan yang di sebabkan oleh faktor patologis. Karena di sebabkan oleh serangan bakteri atau jamur, lendir yang keluar warna kekuningan bahkan kecoklatan dan bahkan terkadang bercampur darah. Selain jamur dan bakteri, keputihan patologis juga bisa dipicu oleh pemakaian obat anti elergi atau obat antikanker pada alat kelamin (Tetty, 2003).

Keputihan normal atau fisiologis tidak perlu diobati tetapi yang harus diwaspadai adalah keputihan patologis jika dirasa mulai mengganggu seperti munculnya rasa gatal dan nyeri maka harus segera dikonsultasikan kedokter sebab, gangguan ini dapat menyebabkan kemandulan dan kanker (Prayitno, 2014). 
Di Indonesia terapi herbal mulai berkembang dan diminati dengan kecenderungan kembali ke alam "back to nature". Salah satu tumbuhan obat yang digunakan oleh masyarakat Indonesia sebagai terapi herbal adalah tanaman daun sirih. Sejak zaman dahulu, tanaman ini memiliki berbagai khasiat obat untuk menyembuhkan berbagai jenis penyakit. Bagian tanaman sirih yang paling banyak digunakan sebagai obat adalah daunnya (Rosdiana, 2014).

Dari hasil penelitian tentang pengujian khasiat dan manfaat dari tanaman daun sirih ini, diperoleh sekitar $90,9 \%$ pasien yang menggunakan daun sirih dinyatakan sembuh. Sedangkan pada kelomok pasien yang diberi placebo hanya $54,5 \%$ saja yang mendapat penyembuhan (Rosdiana, 2014).

Tujuan penelitian untuk mengetahui hubungan pengetahuan dengan sikap remaja putri tentang rebusan daun sirih dalam mengatasi keputihan di SMAN 11 Pekanbaru.

\section{METODE PENELITIAN}

Jenis penelitian adalah analitik dengan desain cross sectional corelative. Penelitian dilakukan pada bulan Mei 2016 di SMAN 11 Pekanbaru. Populasi dalam penelitian ini adalah semua siswi di SMAN 11 Pekanbaru berjumlah 432. Sampel penelitian 82 orang yang diambil secara purposive sampling. Variabel Independen dalam penelitian ini adalah pengetahuan dan sikap. Variabel dependen adalah rebusan daun sirih. Alat pengumpul data yaitu kuesioner. Pengolahan data dilakukan dengan editing, coding, processing dan cleaning. Analisa univariate untuk melihat distribusi frekuensi dengan menggunakan rumus persentase. Analisa bivariate untuk mengetahui ada atau tidak hubungan pengetahuan dan sikap remaja putri tentang rebusan daun sirih dalam mengatasi keputihan. Uji statistik yang digunakan adalah chi-square.

\section{HASIL}

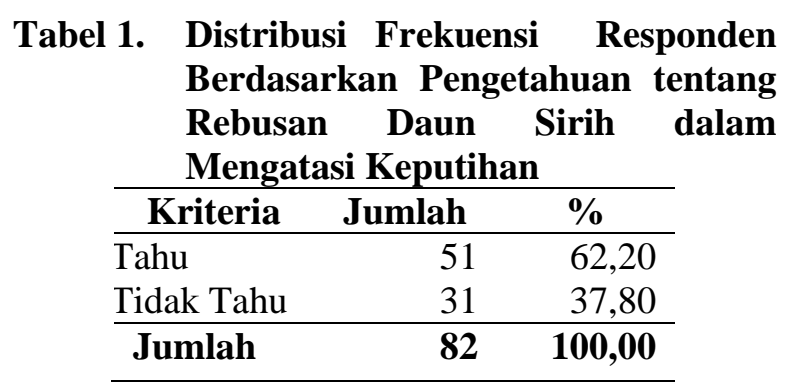

Pada Tabel 1 menunjukkan bahwa pengetahuan responden tentang rebusan daun sirih dalam mengatasi keputihan sebagian besar adalah kategori tahu sebanyak 51 orang $(62,20 \%)$. Sebagian kecil responden tidak tahu sebanyak 31 orang $(37,80 \%)$.

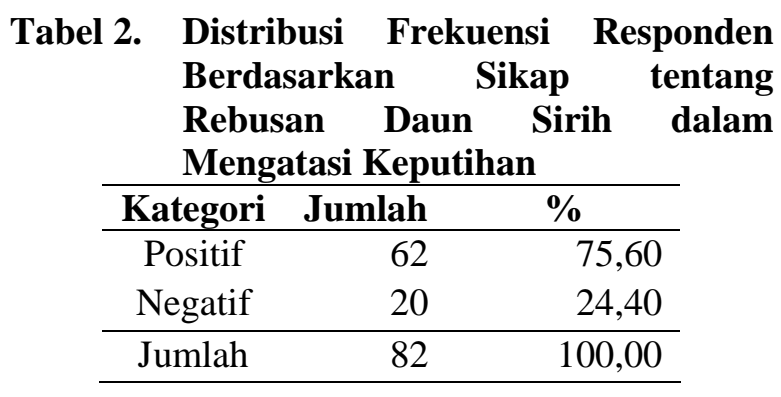

Pada Tabel 2 menunjukkan bahwa sebagian besar responden mempunyai sikap positif tentang penggunaan rebusan daun sirih dalam mengatasi keputihan yaitu sebanyak 62 orang $(75,60 \%)$ dan sebagian kecil mempunyai sikap negatif yaitu sebanyak 20 orang $(24,40 \%)$.

Tabel 3. Hubungan Pengetahuan Dengan Sikap Remaja Putri Tentang Rebusan Daun Sirih dalam Mengatasi Keputihan

\begin{tabular}{lcccccccc}
\hline Pengetahuan & \multicolumn{3}{c}{ Kategori Sikap } & \multicolumn{2}{c}{ Total } & p-value & OR (95\% CI) \\
\cline { 2 - 9 } & \multicolumn{2}{c}{ Positif } & \multicolumn{2}{c}{ Negatif } & f & \% & & \\
\cline { 2 - 9 } & f & \% & f & \% & & & & \\
\hline Tahu & 45 & 88,2 & 6 & 11,8 & 51 & 100 & 0,002 & 6.176 \\
Tidak Tahu & 17 & 54,8 & 14 & 45,2 & 31 & 100 & & $(2.041-18.690)$ \\
\hline Jumlah & 62 & 75,6 & 20 & 24,4 & 82 & 100 & & \\
\hline
\end{tabular}

Berdasarkan Tabel 3, dari 51 responden memiliki pengetahuan kategori tahu sebanyak 45 orang $(88,2 \%)$ bersikap positif, sedangkan dari 31 responden memiliki pengetahuan kategori tidak tahu sebanyak 17 orang $(53,8 \%)$ bersikap positif. Hasil uji statistik diperoleh nilai $p$-value $0,002(p<0,05)$, hal ini berarti bahwa ada hubungan pengetahuan dengan sikap remaja putri tentang rebusan daun sirih dalam mengatasi keputihan di SMAN 11 Pekanbaru Tahun 2016. Dan nilai OR diperoleh 6,176 yang berarti bahwa responden yang memiliki pengetahuan kategori tahu memiliki sikap positif 6,176 kali lebih besar tentang rebusan daun sirih dalam mengatasi 
keputihan jika dibandingkan dengan responden yang pengetahuan tidak tahu.

\section{PEMBAHASAN}

Keputihan (leukorea) menjadi salah satu tanda dan gejala adanya kelainan pada organ wanita. Keputihan walaupun tidak berbahaya cukup menganggu penderita baik fisik maupun mental. Sifat dan banyaknya keputihan dapat memberi petunjuk kearah etiologinya. Jumlah wanita di dunia yang pernah mengalami keputihan sekitar $75 \%$ dan di Indonesia wanita yang mengalami keputihan sekitar 75\% (Mustika, 2014).

Berdasarkan hasil penelitian diperoleh pengetahuan responden sebagian besar adalah kategori tahu sebanyak 51 orang $(62,20 \%)$. Menurut Notoatmodjo (2012), pengetahuan merupakan hasil dari tahu, dan ini terjadi setelah orang melakukan penginderaan terhadap suatu objek tertentu. Penginderaan terjadi melalui panca indra manusia, yakni indra penglihatan, pendengaran, penciuman, perasa, dan peraba. Pengetahuan atau kognitif merupakan domain yang sangat penting dalam membentuk tindakan seseorang (over behavior).

Tingkat pendidikan dapat menentukan mudahnya tidaknya seseorang menyerap dan memahami pengetahuan. Hal yang sama juga dikemukan oleh Melino (2007), bahwa pendidikan adalah suatu proses pendewasaan manusia melalui pengajaran dan pelatihan. Pada penelitian ini yang menjadi responden adalah siswi SMA. Berdasarkan Undang-undang Sistem Pendidikan Nasional tahun 2003 Bab 4 pasal 14 menyatakan bahwa SMA merupakan jenjang pendidikan formal yaitu tingkat pendidikan menengah. Menurut Notoatmodjo (2010) menyatakan bahwa seseorang yang memiliki tingkat pendidikan tinggi tidak sama pemahamannya dengan orang yang berpendidikan rendah. Semakin tinggi pendidikan seseorang maka semakin mudah pula untuk menerima informasi dan pada akhirnya semakin banyak pengetahuan yang mereka miliki.

Responden pada penelitian ini berada di lingkungan sekolah yang merupakan terjadinya interaksi dan pertukaran informasi, sehingga akan memberikan pengetahuan serta reaksi atau respon terhadap informasi. Hal ini didukung oleh Wawan (2011) bahwa lingkungan adalah segala sesuatu yang ada disekitar individu baik lingkungan fisik, biologis maupun sosial. Lingkungan berpengaruh terhadap proses masuknya pengetahuan ke dalam indvidu yang berbeda dalam lingkungan tersebut. Hal ini terjadi karena adanya interaksi timbal balik ataupun yang direspon sebagai pengetahuan oleh setiap individu.

Berdasarkan hasil penelitian diperoleh sikap responden sebagian besar adalah positif yaitu sebanyak 62 orang $(75,60 \%)$. Menurut Notoatmodjo (2010), sikap merupakan reaksi atau respon yang masih tertutup dari seseorang terhadap suatu stimulasi atau objek. Seseorang akan memberikan sikap yang positif jika mempunyai landasan pengetahuan yang kuat terlebih dahulu.

Hasil uji statistik dengan uji chi-square diperoleh nilai $p$-value $0,002(p<0,05)$, hal ini menunjukkan bahwa ada hubungan pengetahuan dengan sikap remaja putri tentang rebusan daun sirih dalam mengatasi keputihan. Dan nilai OR diperoleh 6,176 yang berarti bahwa responden yang memiliki pengetahuan kategori tahu memiliki sikap positif 6,176 kali lebih besar tentang rebusan daun sirih dalam mengatasi keputihan jika dibandingkan dengan responden yang pengetahuan tidak tahu.

Menurut Sarwono (2011), bahwa sikap dapat berubah-ubah sesuai dengan keadaan lingkungan di sekitar individu yang bersangkutan pada saat dan tempat yang berbeda. Sikap dinyatakan dalam tiga domain yaitu ABC (Affect, Behaviour dan Cognition). Affect adalah perasaan yang timbul (senang, tidak senang), Behaviour adalah prilaku yang mengikuti perasaan yaitu menghindar atau mendekat, Cognition adalah penilaian terhadap objek sikap (bagus atau tidak bagus). Pada penelitian ini remaja yang berpengetahuan kategori tahu tentang rebusan daun sirih dalam mengatasi keputihan, maka remaja akan merasa senang dan bersikap positif atau mendukungnya.

Menurut asumsi peneliti, bahwa seseorang yang mendapatkan informasi-informasi baik dari lingkungan formal maupun normal, baik secara langsung maupun tidak langsung akan memperoleh hasil tahu atau pengetahuan. Dan apabila memiliki hasil tahu, maka seseorang akan memberikan reaksi atau respon positif terhadap informasi yang diperoleh. Hal ini sesuai dengan teori Notoatmodjo (2010), bahwa pengetahuan dibagi menjadi enam tingkat yaitu; tahu, memahami, aplikasi, analisis, sintesis dan evaluasi. Selanjutnya setelah di evaluasi maka seseorang akan memberikan respon atau sikap. Menurut Wawan \& Dewi (2011) sikap adalah evaluasi umum yang dibuat manusia terhadap dirinya sendiri, orang lain, objek atau isu. Sehingga komonen afektif berhubungan dengan bagaimana perasaan yang timbul pada seseorang 
yang menyertai sikap, bisa positif dan negatif terhadap objek sikap.

\section{SIMPULAN}

1. Distribusi frekuensi remaja putri berdasarkan pengetahuan tentang rebusan daun sirih dalam mengatasi keputihan di SMAN 11 Pekanbaru tahun 2016 yaitu kategori tahu sebanyak 51 responden $(62,20 \%)$.

2. Distribusi frekuensi remaja putri berdasarkan sikap tentang rebusan daun sirih dalam mengatasi keputihan di SMAN 11 Pekanbaru tahun 2016 yaitu kategori positif sebanyak 62 responden $(75,60 \%)$.

3. Ada hubungan pengetahuan dengan sikap remaja putri tentang rebusan daun sirih dalam

\section{DAFTAR PUSTAKA}

Melino, dkk. 2007. MPKT Modul I. FEUI. Jakarta. $\quad$ http://id.wikipedia.org/wiki/ (Diakses tanggal 12 Oktober 2016).

Mustika, dkk. 2014. Penggunaan Air Rebusan Daun Sirih Terhadap Keputihan Fisiologis di Kalangan Remaja Putri Mahasiswa Poltekkes Denpasar. Jurnal Skala Husada. Volume 11, 101-106. Jurusan Keperawatan Poltekkes Denpasar. Bali.

Notoatmodjo, Soekidjo. 2010. Promosi Kesehatan Teori \& Aplikasi. Jakarta: Rineka Cipta.

Notoatmodjo, Soekidjo. 2012. Metodologi Penelitian Kesehatan. Jakarta: Rineka Cipta. mengatasi keputihan di SMAN 11 Pekanbaru tahun 2016 ( $p$-value 0,$002 ; \mathrm{OR}=6,176$ ).

\section{SARAN}

1. Bagi pihak SMAN 11 Pekanbaru diharapkan hasil penelitian ini dapat dijadikan salah satu pertimbangan dalam upaya peningkatan kesehatan reproduksi pada remaja dengan bekerjasama dengan pihak Puskesmas terdekat dalam memberikan penyuluhan tentang rebusan daun sirih dalam mengatasi keputihan.

2. Bagi peneliti selanjutnya agar dapat meneliti tentang variable lain yang berhubungan dengan rebusan daun sirih dalam megatasi keputihan seperti sosial budaya, kebiasaan dan perilaku.

Prayitno, Sunyoto. 2014. Kesehatan Organ Reproduksi Wanita. Jogjakarta: Saufa.

Rosdiana, Anna, Pratiwi, Wulan Mulya. 2014. Khasiat Ajaib Daun Sirih. Jakarta: Padi.

Sarwono. S.W. 2011. Psikologi Remaja. Jakarta: PT Raja Grafindo Persada.

Tetty. 2003. Ramuan Tradisional Untuk Mengatasi Aneka Penyakit. Jakarta: Agromedia Pustaka.

Wawan \& Dewi. 2011. Pengetahuan, Sikap, dan Perilaku Manusia. Yogyakarta: Nuha Medika. 